\title{
Comparison of Microbial Infection and its Resistance Pattern in Cell Phone of Health-Care Workers with the Administrative Stuff at a Teaching Hospital
}

\author{
Farhad Sarrafzadeh ${ }^{1}$, Mohsen Valizadeh ${ }^{1}$, Pegah Arfae fathollahkhani ${ }^{1}$ and Seyed Mojtaba Sohrevardi ${ }^{2 *}$ \\ ${ }^{1}$ Department of internal medicine, Kerman University of Medical Sciences, Iran \\ ${ }^{2}$ Department of Clinical Pharmacy, Shahid Sadoughi University of Medical Sciences, Iran
}

Submission: February 03, 2017; Published: August 14, 2017

*Corresponding author: Seyed Mojtaba Sohrevardi, Department of Clinical Pharmacy, Faculty of Pharmacy, Shahid Sadoughi University of Medical Sciences, Yazd, Iran, Email: pegaharfa15@gmail.com

\begin{abstract}
In recent several decades, despite significant progress in treatment and prevention, microbes also have the power to escape from the clutches of best weapons; Direct contact is the main route of the infection transmission in hospital, so we decided to compare frequency and pattern of microbial contamination and resistance in cell phone of healthcare workers (HCWs) and administrative staffs in Afzalipour Hospital.

In this descriptive \& cross-sectional study, 200 samples were collected by using Quota sampling. These samples of cell phone stuff were collected by using sterile swab and cultured in Blood Agar and EMB medium and then were measured sensitivity of bacterial resistance.

In this comparison, HCWs had 61.6\% contamination (Staph. Coagulase- 29/7\%, MRSA+8/9\%, MRSA-17/8\%) and administrative staffs had $62.4 \%$ contamination (Staph. Coagulase- $41 / 4 \%, M R S A+3 \%, M R S A-9 / 1 \%$ ) that there wasn't significant difference among two groups (p.v=0/073) but in the HCWs, residents group had most contamination and professors group had low one. Also in HCWs, MRSA cases were three times more than administrative staffs. In addition, in HCWs, three sample gram negative bacteria grew include Neisseria, E.coli and Kelebsiela. It was not found in any of the administrative staff and it is important.
\end{abstract}

In this study, in spite of lack of significant differences between groups of HCWs and administrative staff, finally recommended, cell phones of both groups, every day to be disinfected by standard antiseptic solution.

Keywords: Microbial infection; Cell phone; Stuff; Kerman Afzalipour hospital

\section{Introduction}

In recent several decades, despite significant progress in treatment and prevention, infectious disease are considered one of the major causes of death, residual disability, and responsible for the deterioration of the living conditions of millions of people around the world. Infectious disease frequently challenged medical diagnostics skills and should be taken into consideration in differential diagnosis of any syndrome that affects each body systems.

With the introduction of antimicrobial drugs, some medical pioneers convinced that infectious diseases will soon be disappeared and only will be valuable from a historical perspective. Of course, since Second World War have been made hundreds of chemical compositions, majority of them are strong \& safety and include drugs which are effective not only on bacteria but also viruses, fungi and parasites. However, today we realize the fact that along with the progress in construction of new and effective drugs, microbes also have the power to escape from the clutches of best weapons and to engage counterattack by new strategies. Resistance against antibiotics arises from alarming speed among all mammalian pathogens.

Hospital infections are a major problem in all modern hospitals. In early 1861, Semmelweis [1] show that bacteria from contaminated hands of healthcare workers were transferred to patients. Hospital operating rooms and intensive care units are places that have enjoyed the highest standards of hygiene and there are similar conditions for other stuff and used equipment by them. Also, some epidemiological studies show that environmental levels of bacteria are involved in the transfer.

On the other part, the most common way of transmission of nosocomial infections, including resistant bacteria are mainly through the contact. Treatment of these infections is very difficult and they have very high morbidity and mortality as well 
as increased health care costs and imposes a huge cost to society, so, we decided to do this study on cell phone of health care stuff (HCWs) such as professors, residents, interns and nurses compared with hospital administrative stuff; so that we can know a lot of microbes on the status of antimicrobial resistance and using it to do things for reducing hospital infections and morbidity and mortality caused it.

In a study of Dutta et al. [2] in 2009 in India on bacterial contamination of HCWs mobile phone was shown that hospital infections are still a factor for increasing mortality and morbidity of patients and HCWs hands play an important role in the transmission of these infections.

In a similar study carried out by Brady et al. [3] in England and Karabay et al. [4] in Turkey, separation amount of Gramnegative bacilli of mobile phones were $76 / 4 \%$ and $2 / 7 \%$ respectively, and contamination amount of mobile phones with hospital infections in Turkey was $9 \%$ and in a study of Brady and et al was $\% 14$.

Fatma Ulger et al. [5] in 2009 in Turkey by examining cell phones, reported $94 / 5 \%$ microbial contamination that staph aureus was observed in $52 \%$ of separation and gram-negative bacteria's were observed in $3 / 31 \%$ of cases.

Considering that health care staff equipment are at risk of infection with bacterial species and can transfer many infects from outside hospital into it and from inside hospital to outside and even into own it and since this species can change and resist over time, it is necessary to know and better understand them, we prevent from spread of infections in hospital environments. So, in order to better understand it, we compare it with control group (hospital administrative staff) [6].

\section{Materials and Methods}

This study was carried out in a descriptive and crosssectional form in 2014. The studied populations were professors, assistants, interns, nurses and administrative staff of Afzalipour hospital in Kerman and sampling was performed in a form of quota sampling. Finally, were selected 200 people of sample (include: 100 samples of cell phone of health care workers and100 samples of administrative stuff cell phone and from all sections of the hospital such as: administrative, emergency, surgery, pediatrics, infectious diseases, dermatology, gastrointestinal, lung, gynecology, endocrinology, NICU, CCU, ICU. Stuff information was acquired using questionnaire. These information included job valuables: (Employee, Professor, Table 3: Comparison of abundance of mobile type in the two study groups.

\begin{tabular}{|c|c|c|c|c|c|c|c|}
\hline \multirow{2}{*}{ Number } & \multirow{2}{*}{ Type of cell } & \multicolumn{2}{|c|}{ Health care } & \multicolumn{2}{|c|}{ Administrative } & \multicolumn{2}{|c|}{ Total } \\
\cline { 3 - 9 } & & abundance & percent & abundance & percent & abundance & percent \\
\hline 1 & Keyboard & 55 & $\% 55 / 6$ & 43 & $\% 43 / 6$ & 98 & $49 \%$ \\
\hline 2 & Touch & 45 & $\% 44 / 4$ & 57 & $\% 57 / 4$ & 102 & $51 \%$ \\
\hline
\end{tabular}

Resident, Intern, nurse), age, gender (male, female), sections of respective hospital (professional, surgery, internal) and type of mobile (key board, Touch). Then, sampling were taken by using a sterile swab from both sides of cell phone, back and forth, in a on culture medium of "Blood Agar", containing \%5 of sheep blood and Eosin Methylene Blue Agar (EMB), then, the plates were incubated for 48 hours at $3{ }^{\circ} \mathrm{C}$.

Then, we separated them according to colony growth and morphology and Gram stain and in the next step; we studied bacteria causing hospital infections including bacilli, negativepositive gram in a specific culture medium. Then, using discs impregnated with antibiotics we assess sensitivity and resistance of bacteria and investigate relative-absolute abundance, after analyzing data, using SPSS software. Also, it was used chi-square or fisher test for analytical statistics $[7,8]$.

\section{Results}

Table 1: Abundance of jobs and hospital units in the medical staff.

\begin{tabular}{|c|c|c|c|c|}
\hline Number & & & Abundance & Percent \\
\hline 1 & \multirow{4}{*}{ Job } & Professor & 22 & $22 \%$ \\
\hline 2 & & Resident & 21 & $21 \%$ \\
\hline 3 & & Intern & 22 & $22 \%$ \\
\hline 4 & & Nurse & 35 & $35 \%$ \\
\hline 1 & \multirow{3}{*}{$\begin{array}{c}\text { Hospital } \\
\text { unit }\end{array}$} & Internal & 43 & $43 \%$ \\
\hline 2 & & Surgery & 32 & $32 \%$ \\
\hline 3 & & ICU & 25 & $25 \%$ \\
\hline
\end{tabular}

Table 2: Comparison of gender abundance in the two study groups.

\begin{tabular}{|c|c|c|c|}
\hline Number & Gender & \multicolumn{2}{|c|}{ Medical Care } \\
\hline & & abundance & percent \\
\hline 1 & male & 28 & $\% 28 / 3$ \\
\hline 2 & female & 72 & $\% 71 / 7$ \\
\hline
\end{tabular}

In this study, 200 people of health care workers include 22 professors, 21 assistants, 22 interns, and 35 nurses and abundance of them in the hospital sections was as follow: 43 people in internal unit, 32 people in surgery unit and 25 people in ICU (Table 1). From this number, $28 / 3 \%$ male and $71 / 7 \%$ female were in HCWs group and also, 32/7\% male and 67/3\% female were in administrative stuff group (Table 2). way that to be done all levels of sampling. Swabs were cultured 


\section{Current Trends in Biomedical Engineering \& Biosciences}

Table 4: Comparison of microbial contamination type abundance, in two study groups.

\begin{tabular}{|c|c|c|c|c|c|c|c|c|}
\hline \multirow{3}{*}{ Number } & \multirow{3}{*}{$\begin{array}{c}\text { Type of } \\
\text { contamination }\end{array}$} & \multicolumn{4}{|c|}{ Groups under study } & \multirow{2}{*}{\multicolumn{2}{|c|}{ Total Administrative }} & \multirow{2}{*}{ P.V } \\
\hline & & \multicolumn{4}{|c|}{ Medical care } & & & \\
\hline & & abundance & percent & abundance & percent & abundance & percent & \multirow{9}{*}{$0 / 073$} \\
\hline 1 & No Growth & 39 & $38 / 4$ & 37 & $37 / 6$ & 76 & 38 & \\
\hline 2 & Staph. Coagulase & 29 & $29 / 7$ & 41 & $41 / 4$ & 70 & $35 / 5$ & \\
\hline 3 & MRSA & 9 & 9-Aug & 3 & 3 & 12 & 6 & \\
\hline 4 & MSSA & 18 & $17 / 8$ & 9 & 1-Sep & 37 & $13 / 5$ & \\
\hline 5 & Rods & 3 & 3 & 8 & 1-Aug & 11 & 5-May & \\
\hline 6 & Neisseria & 1 & 1 & 0 & 0 & 1 & $0 / 5$ & \\
\hline 7 & Kelebsiela & 1 & 1 & 0 & 0 & 1 & $0 / 5$ & \\
\hline 8 & E.coli & 1 & 1 & 0 & 0 & 1 & $0 / 5$ & \\
\hline
\end{tabular}

Table 5: Comparison of microbial contamination type abundance in two study groups based on job.

\begin{tabular}{|c|c|c|c|c|c|c|c|c|c|c|}
\hline \multirow{3}{*}{ Numbers } & \multirow{3}{*}{$\begin{array}{c}\text { Type of } \\
\text { Contamination }\end{array}$} & \multicolumn{8}{|c|}{ Job } & PV \\
\hline & & \multicolumn{2}{|c|}{ Professor } & \multicolumn{2}{|c|}{ Resident } & \multicolumn{2}{|c|}{ Intern } & \multicolumn{2}{|c|}{ Nurse } & \multirow{9}{*}{$0 / 001$} \\
\hline & & abundance & percent & abundance & percent & abundance & percent & $\mathbf{A}$ & p & \\
\hline 1 & No Growth & 13 & $59 / 1$ & 5 & $23 / 8$ & 10 & $40 / 9$ & 11 & $31 / 4$ & \\
\hline 2 & Staph. Coagulase & 1 & 5-Apr & 11 & $52 / 4$ & 2 & 1-Sep & 15 & $42 / 9$ & \\
\hline 3 & MRSA & 1 & 5-Apr & 1 & 8-Apr & 3 & $13 / 6$ & 4 & 4-Nov & \\
\hline 5 & Rods & 3 & $13 / 6$ & 0 & 0 & 0 & 0 & 0 & 0 & \\
\hline 6 & Neisseria & 0 & 0 & 0 & 0 & 1 & 5-Apr & 0 & 0 & \\
\hline 7 & Kelebsiela & 0 & 0 & 0 & 0 & 1 & 5-Apr & 0 & 0 & \\
\hline 8 & E.coli & 0 & 0 & 0 & 0 & 0 & 0 & 1 & 9-Feb & \\
\hline
\end{tabular}

Table 6: Comparison of microbial contamination type abundance in two study groups based on hospital units.

\begin{tabular}{|c|c|c|c|c|c|c|c|c|}
\hline \multirow{3}{*}{ Number } & \multirow{3}{*}{$\begin{array}{c}\text { Type of } \\
\text { contamination }\end{array}$} & \multicolumn{6}{|c|}{ Type of mobile } & \multirow{2}{*}{ PV } \\
\hline & & \multicolumn{2}{|c|}{ Keyboard } & \multicolumn{2}{|c|}{ Touch } & \multicolumn{2}{|c|}{ Total } & \\
\hline & & abundance & percent & abundance & percent & abundance & percent & \\
\hline 1 & No Growth & 35 & $35 / 7$ & 41 & $40 / 2$ & 76 & 38 & \\
\hline 2 & Staph.coagulase & 38 & $38 / 8$ & 33 & $32 / 4$ & 71 & $35 / 5$ & \\
\hline 3 & MRSA & 3 & 1-Mar & 9 & 8-Aug & 12 & 6 & \\
\hline 4 & MSSA & 16 & $16 / 3$ & 11 & 8-Oct & 27 & $35 / 5$ & \\
\hline 5 & Rods & 4 & 1-Apr & 7 & 9-Jun & 11 & 5-May & \\
\hline 6 & Neisseria & 1 & 1 & 0 & 0 & 1 & $0 / 5$ & $0 / 291$ \\
\hline 7 & Kelebsiela & 0 & 0 & 1 & 1 & 1 & $0 / 5$ & \\
\hline 8 & E.coli & 1 & 1 & 0 & 0 & 1 & $0 / 5$ & \\
\hline
\end{tabular}

In the part related to mobile type: $55 / 6 \%$ of cell phones of HCWs were from type of Keyboard and $44 / 6 \%$ from type of touch. Also, $42 / 6 \%$ of cell phones of administrative stuff were from type of Keyboard and 57/4\% were from type of touch (Table 3). In the part of comparison of microbial contamination abundance, in two study groups statistically, there was no significant difference between a group of HCWs and administrative stuff (Table 4). In the part of comparison of microbial contamination type abundance, in two study groups there was no significant difference (P.V-0/001) based on job. The lowest pollution is related to professors group (59/1\%, No Growth), the highest pollution is related to assistances group (23/8\%, No Growth) (Table 5). In comparison of microbial contamination type abundance in two study groups there was no significant difference (P.V-0/294) based on hospital units (Table 6). Also, in comparison of microbial contamination type abundance in two study groups there was no significant difference (P.V-0/291) based on mobile type (Table 7) [9]. 
Current Trends in Biomedical Engineering \& Biosciences

Table 7: Comparison of microbial contamination type abundance in two study groups based on mobile type.

\begin{tabular}{|c|c|c|c|c|c|c|c|c|}
\hline \multirow{3}{*}{ Number } & \multirow{3}{*}{$\begin{array}{c}\text { Type of } \\
\text { contamination }\end{array}$} & \multicolumn{6}{|c|}{ Type of mobile } & \multirow{2}{*}{ PV } \\
\hline & & \multicolumn{2}{|c|}{ Keyboard } & \multicolumn{2}{|c|}{ Touch } & \multicolumn{2}{|c|}{ Total } & \\
\hline & & abundance & percent & abundance & percent & abundance & percent & \multirow{9}{*}{$0 / 291$} \\
\hline 1 & No Growth & 35 & $35 / 7$ & 41 & $40 / 2$ & 76 & 38 & \\
\hline 2 & Staph.coagulase & 38 & $38 / 8$ & 33 & $32 / 4$ & 71 & $35 / 5$ & \\
\hline 3 & MRSA & 3 & 1-Mar & 9 & 8-Aug & 12 & 6 & \\
\hline 4 & MSSA & 16 & $16 / 3$ & 11 & 8-Oct & 27 & $35 / 5$ & \\
\hline 5 & Rods & 4 & 1-Apr & 7 & 9-Jun & 11 & 5-May & \\
\hline 6 & Neisseria & 1 & 1 & 0 & 0 & 1 & $0 / 5$ & \\
\hline 7 & Kelebsiela & 0 & 0 & 1 & 1 & 1 & $0 / 5$ & \\
\hline 8 & E.coli & 1 & 1 & 0 & 0 & 1 & $0 / 5$ & \\
\hline
\end{tabular}

\section{Discussion}

Microbial resistance is very important problem that unfortunately, its prevalence is increasing in society. In this study, 100 people of Health care workers participates such as 22 Professor, 21 Resident, 22 Intern, and 35 Nurse. 43 people were in internal unit, 32 people in surgery unit, and 25 people in ICU. Also, 100 people were selected among administrative stuff [10]. Obtained information was analyzed by statistical group, after collecting data by registration form and culture and antiprogram of mobile phone of stuff.

In general, amount of abundance of microbial contamination in health care workers is $61 / 6 \%$ and this amount in administrative stuff is $62 / 4 \%$ and there was no significant difference, but, amount of methicillin-resistant Staphylococcus aureus (MRSA) in cell phone of health care workers was 9 case and in administrative stuff was 9 case that there was 3 doubled difference. Also in health care workers group, three examples of Gram-negative bacilli such as Neisseria, Klebsiella E. coli were grew that did not in the administrative stuff. These bacteria were found in introns and nurses and in all studied units. Two sample of these bacteria were grew keyboard-type cell phones and one sample was grew in touch-type cell phone.

In a study that P Datta et al. [2] (2009) were performed in Netherland about bacterial contamination of cell phone of HCWs group, from 200 samples, 144 ones equivalent to $72 \%$ were reported microbial contamination that $18 \%$ of them were MRSA cases that in a study conducted by us, $6 / 61$ of microbial contamination 9.8 percent of MRSA were found.

In another study performed by Braddy RR et al. [3] in England and Karabay 0 et al. [4] in Turkey, amount of mobile phone Gram-negative bacilli was respectively $4 / 76$ and $7 / 2$. In our study, this amount was equal to $3 \%$ and we see a less percentage [11,12].

\section{Conclusion}

In short, results obtained from the study demonstrate that despite significant differences in microbial contamination on Mobile phone of HCWs group, a resident have the highest and professors had the least pollution, there was no significant difference among microbial contamination in mobile phones of HCWs group and administrative stuff. Some of infectious microorganisms such as Staphylococcus aureus could be contaminants in both groups; but infection with gram-negative microorganisms were found only in HCWs that shows the effects Clinical Affairs on this issue. Finally, it is advisable that were considered necessity strategies for eliminating infectious agents contaminating from devices of hospital staff and attempt to control it.

\section{References}

1. Semmelweis IP: Die Aetilogie, der Begriff und die Prophylaxis des Kindbettfiebers. Budapest CA Hartleben's Verlags-Expedition, 1861.

2. Datta P, Rani H, Chander J, Gupta V (2009) Bacterial contamination of mobile phones of health care workers. Indian J Med Microbiol 27(3): 279-281.

3. Brady RR, Fraser SF, Dunlop MG, Paterson - Brown S, Gibb AP (2007) Bacterial contamination of mobile communication devices in the operative environment. J Hosp Infect 66(4): 397-398.

4. Karabay O, Kocoglu E, Tahtaci M (2007) The role of mobile phones in the spread of bacteria associated with nosocomial infections. J Infect Developing Countries 1: 72-73.

5. Ulger F, Esen S, Dilek A, Yanik K, Gunaydin M, et al. (2009) Are we aware how contaminated our mobile phones whit nasocomial pathogens? Ann Clin Microbiol Antimicrob 8: 7.

6. Longo DL, Fauci AS, Dennis L kasper DL, Stephen Hauser J, larry Jameson, et al. (2010) Harrisons principles of internal medicine $18^{\text {th }}$ (edn), McGraw Hill Medical, USA.

7. Brady RR, Wasson A, Stirling I, McAllister C, Damani N (2006) Is your phone bugged? The incidence of bacteria known to cause nosocomial infection on healthcare worker's mobile phones. J Hosp Infect 62(1): 123-125.

8. Ekanem EE, Dupont HL, Pickering LK, Selwyn BJ, Hawkins CM (1983) Transmission dynamics of enteric bacteria in day-care centers. Am J Infect Control 118(2): 562-572.

9. Manning ML, Archibald LK, Bell LM, Banerjee SN, Jarvis WR (2001) Serratiamarcescens transmission in a pediatric intensive care unit: a multifactorial occurrence. Am J Infect Control 29(2): 115-119.

10. Bures S, Fishbain JT, Uyehara CF, Parker JM, Berg BW (2000) Computer keyboards and faucet handles as reservoirs of nosocomial pathogens in the intensive care unit. Am J Infect Control 28(6): 465-471. 
11. Sarafzadeh F, Sohrevardi SM, Gharehghozli M, Ahmadinejad M (2010) Detection of the most common microorganisms and their resistance against anti-microbials in intubated patients in an icu in kerman, iran. Iran J Pharm Res 9(4): 437-443.
12. Sarrafzadeh F, Sohrevardi SM (2013) Evaluation of bactereuria and antimicrobial susceptibility among hospitalized patients with and without catheter in kerman province- iran in 2011. Iran J Pharm Res 12(1): 211-216.

\section{Your next submission with Juniper Publishers} will reach you the below assets

- Quality Editorial service

- Swift Peer Review

- Reprints availability

- E-prints Service

- Manuscript Podcast for convenient understanding

- Global attainment for your research

- Manuscript accessibility in different formats ( Pdf, E-pub, Full Text, Audio)

- Unceasing customer service

Track the below URL for one-step submission https://juniperpublishers.com/online-submission.php 